\title{
PENGARUH PERBEDAAN MOLASES SEBAGAI PENYUSUN UREA MOLASES BLOK (UMB) TERHADAP KUALITAS FISIK PAKAN
}

\author{
Effect of Diferences Molasses As A Composer Urea Molasses Blok (Umb) on \\ The Physical Quality of Feed \\ Yuli Frita Nuningtyas ${ }^{1)}$, Poespitasari Hazanah Ndaru ${ }^{1)}$, Asri Nurul Huda ${ }^{1)}$ \\ ${ }^{1)}$ Dosen Fakultas Peternakan Universitas Brawijaya Jalan Veteran, Ketawanggede, Kec. Lowokwaru, Kota \\ Malang, Jawa Timur 65145 \\ E-mail: fritanuningtyas@ub.ac.id
}

\begin{abstract}
ABSTRAK
Penelitian ini bertujuan untuk mengetahui kualitas fisik Urea Molases Blok (UMB) dengan perbedaan komposisi pemberian molases yang berbeda. Kualitas fisik yang diamati meliputi warna, tekstur, aroma, dan tumbuhnya miselia/jamur. Metode yang digunakan pada penelitian ini menggunakan metode Rancangan Acak Lengkap (RAL). Sampel yang dianalisis dibedakan menjadi 5 perlakuan dan setiap perlakuan dilakukan pengulangan sebanyak 6 kali. Perlakuan terdiri dari P1 (molases 30\%), P2 (molases 32,5\%), P3 (molases 35\%), P4 (molases 37,5\%), dan P5 (molases 40\%). Penambahan molases pada UMB sampai dengan 40\% menunjukkan hasil yang baik ditinjau dari warna, aroma, miselia, dan tekstur.
\end{abstract}

Kata kunci: Aroma, miselia, molases, tekstur, urea molases blok, warna

How to Cite :

Nuningtyas, Y. F., Ndaru, P. H., \& Huda, A. N. (2019).

Pengaruh Perbedaan Molases Sebagai Penyusun Urea

Molases Blok (UMB) Terhadap Kualitas Fisik Pakan.

Jurnal Nutrisi Ternak Tropis, 2 (1) 70-74
*Corresponding author :

Yuli Frita Nuningtyas

Email : fritanuningtyas@ub.ac.id

Fakultas Peternakan Universitas Brawijaya Jalan Veteran, Ketawanggede, Kec. Lowokwaru, Kota Malang, Jawa Timur 65145 


\begin{abstract}
The aim of the research was to evaluate the effect of differences molasses as a composer Urea Molasses Block (UMB) on the physical quality of feed. Physical quality of UMB was evaluate by colour, texture, oddour, and fungi. The experiment were divided into 5 treatments; there were 6 replications in every treatment. The treatment were used molasses 30\%, 32,5\%, $35 \%, 37,5 \%$, and 40\% of the composition UMB. The data was analysed using Compeletely Randomized Design (CRD) and the significant level were analyzed by Duncan Multiple Randomized Design (DMRT). The used of molasses as a composer on UMB was not significantly different on colour, texture, oddour, and fungi. The used molasses up to $40 \%$ had a good results in term of brown colour, solid texture, fermented oddour, and less fungi.
\end{abstract}

Keywords: Colour, fungi, molasses, oddour, texture

\section{PENDAHULUAN}

Molases adalah produk hasil samping pengolahan tebu yang biasanya dimanfaatkan untuk sumber energi. Molases mengandung gula dan asam organik. Di Indonesia, molases dikenal dengan sebutan tetes tebu. Dimana kandungan sukrosa dalam molases terbilang cukup tinggi yaitu berkisar 48-55\% sehingga digunakan sebagai sumber pembuatan etanol. Molases biasanya berwarna cokelat kental yang selain digunakan sebagai sumber bahan baku pembuatan etanol juga digunakan sebagai bahan baku pembuatan alkohol, asam sitrat, MSG, dan gasohol. Molases memiliki kandungan zat yang bermanfaat untuk hewan dan tanaman diantaranya adalah kalsium, magnesium, potasium, dan besi.

Selain itu molases dapat digunakan sebagai chelating yang baik dalam mengubah zat nutrisi kimia menjadi bentuk yang sederhana sehingga dapat dimanfaatkan oleh hewan dan tanaman (Anwar dan Suganda, 2002). Limbah molases di Indonesia mencapai 1,3 juta ton/tahun dimana akan mengalami peningkatan sampai 1,8 juta ton/tahun (Utami, 2009). Hal ini dapat dimanfaatkan oleh peternak untuk membuat pakan dengan menggunakan molases. Salah satu pakan ternak yang memanfaatkan molases adalah Urea Molases Blok (UMB). UMB merupakan bahan pakan ternak yang biasanya disebut sebagai permen ternak yang tersusun dari bahan seperti molases sebagai sumber energi, urea sebagai sumber nitrogen, dan bahan lain seperti garam, mineral mix, dan semen sebagai bahan pelengkap zat makanan serta bekatul dan dedak sebagai bahan pengisi yang mampu menyerap molases sebagai bahan utama penyusunnya. Selain itu molases dapat dimanfaatkan untuk pembuatan Urea Molases Blok (UMB) karena merupakan sumber karbohidrat yang mudah dicerna oleh hewan ruminansia.

Penggunaan molases sebagai sumber energi dalam penyusunan UMB mempengaruhi kualitas UMB. Sehingga dalam penelitian ini dilakukan untuk mengetahui kualitas UMB secara fisik dengan penambahan molases dengan komposisi yang berbeda-beda.

\section{MATERI DAN METODE}

\section{Materi Penelitian}

Bekatul, pollard, molases, semen, mineral mix, garam, dan urea. 
Metode Penelitian

Metode penelitian terdiri dari 5 perlakuan dan 6 ulangan. Perlakuan pada penelitian adalah dengan penggunaan molases adalah sebagai berikut:

Tabel 1. Komposisi Penyusun Urea Molases Blok (UMB)

\begin{tabular}{llllll}
\hline Bahan & \multicolumn{5}{c}{ Perlakuan (\%) } \\
\cline { 2 - 6 } & P1 & P2 & P3 & P4 & P5 \\
\hline Bekatul & 25 & 22,5 & 20,5 & 20 & 20 \\
Pollard & 25 & 25 & 20,5 & 22,5 & 20 \\
Semen & 15 & 15 & 15 & 15 & 15 \\
Mineral & 24 & 24 & 24 & 24 & 24 \\
Mix & & & & & \\
Garam & 6 & 6 & 6 & 6 & 6 \\
Urea & 15 & 15 & 15 & 15 & 15 \\
Molases & 30 & 32,5 & 35 & 37,5 & 40 \\
\hline
\end{tabular}

\section{Prosedur Pembuatan UMB}

1. Bahan pengisi berupa bekatul dan pollard ditimbang sesuai dengan kebutuhan pada masing-masing perlakuan dan dimasukkan ke dalam nampan.

2. Ditambahkan bahan berupa semen, mineral mix, garam, dan urea.

3. Ditambahkan molases sesuai dengan masing-masing perlakuan.

4. Diaduk rata dan dicetak menggunakan pencetak UMB.

\section{Variabel yang diamati terdiri atas:}

Variabel yang diamati untuk mengetahui keberhasilan dalam penelitian ini adalah warna, aroma, tekstur, dan miselia/jamur.

\section{Analisis Data}

Data yang diperoleh dianalisis statistik menggunakan analisis ragam (ANOVA) dari Rancangan Acak Lengkap (RAL). Selanjutnya untuk mengetahui perbedaan antar perlakuan dilakukan dengan menggunakan Uji Jarak Berganda Duncan.

\section{HASIL DAN PEMBAHASAN}

\section{Pengaruh perlakuan terhadap warna}

Hasil analisis statistik pada Tabel 2. menunjukkan bahwa perlakuan yang dilakukan dalam penyusunan UMB menunjukkan hasil yang tidak berbeda nyata $(\mathrm{P}<0,05)$ terhadap warna UMB. Hasil pengamatan secara kualitatif yaitu warna 1 cokelat keputihan, 2 cokelat muda, 3 cokelat, 4 cokelat tua. Berdasarkan hasil penelitian menunjukkan bahwa pada P1 menunjukkan hasil yang berwarna cokelat tua.

Hasil penelitian (BPTP Bengkulu, 2015) menyatakan bahwa kualitas Urea Molases Blok (UMB) yang bagus berwarna cokelat matang. UMB merupakan bahan tambahan yang diberikan kepada ternak yang bahan utamanya terdiri dari molases sebagai sumber energi, urea sebagai sumber nitrogen, dan bahan lain seperti garam, mineral mix, dan semen sebagai bahan pelengkap zat makanan serta bekatul dan dedak sebagai bahan pengisi yang mampu menyerap molases sebagai bahan utama penyusunnya.

Penggunaan molases sebanyak 30 sampai dengan $40 \%$ dalam campuran UMB menunjukkan warna yang bagus secara berturut-turut yaitu P1 warna cokelat tua (4), P2 warna cokelat tua $(3,7)$, P3 warna cokelat $(3,5), \mathrm{P} 4$ warna cokelat tua $(3,8)$, dan P5 warna cokelat tua $(3,8)$. Hal ini menunjukkan bahwa perlakuan pada Urea Molases Blok (UMB) memberikan warna yang bagus yaitu cokelat tua. 
Tabel 2. Pengaruh Perbedaan Molases Sebagai Penyusun Urea Molases Blok (UMB) Terhadap Uji Kualitas Fisik Pakan

\begin{tabular}{lccccc}
\hline \multirow{2}{*}{ Variabel } & \multicolumn{5}{c}{ Perlakuan (\%) } \\
\cline { 2 - 6 } & $\mathrm{P} 1$ & $\mathrm{P} 2$ & $\mathrm{P} 3$ & $\mathrm{P} 4$ & $\mathrm{P} 5$ \\
\hline Warna & & & & & \\
UMB & $4,0 \pm 0$ & $3,7 \pm 0,8$ & $3,5 \pm 0,8$ & $3,8 \pm 0,4$ & $3,8 \pm 0,4$ \\
Aroma & $1,8 \pm 0,4$ & $2,0 \pm 0$ & $2,0 \pm 0$ & $2,0 \pm 0$ & $2,0 \pm 0$ \\
Miselia & $1,3 \pm 0,5$ & $1,0 \pm 0$ & $1,0 \pm 0$ & $1,0 \pm 0$ & $1,0 \pm 0$ \\
Tekstur & $2,2 \pm 0,8$ & $2,7 \pm 0,5$ & $3,0 \pm 0$ & $2,3 \pm 0,5$ & $2,5 \pm 0,5$ \\
\hline
\end{tabular}

Keterangan: ${ }^{\mathrm{a}, \mathrm{b}, \mathrm{c}, \mathrm{d}}$ superskrip yang berbeda pada kolom yang sama menunjukkan berbeda sangat nyata $(\mathrm{P} \leq 0,01)$

\section{Pengaruh perlakuan terhadap aroma}

Berdasarkan hasil analisis statistik pada Tabel 2. menunjukkan bahwa penggunaan molases pada penyusunan Urea Molases Blok (UMB) menunjukkan hasil yang tidak berbeda nyata $(\mathrm{P}<0,05)$ terhadap aroma UMB. Uji kualitatif terhadap aroma UMB yaitu 1 tidak ada aroma dan 2 beraroma molases. Aroma UMB yang baik memiliki aroma yang segar dan tidak tengik. Utomo (2012) mengatakan bahwa aroma pakan yang segar akan meningkatkan konsumsi oleh ternak. Faktor yang mempengaruhi aroma UMB yaitu bahan baku, lama penyimpanan, dan kandungan nutrisi bahan pakan.

\section{Pengaruh perlakuan terhadap miselia/fungi}

Hasil analisis statistik menunjukkan hasil yang tidak berbeda nyata $(\mathrm{P}<0,05)$ terhadap ada atau tidaknya miselia/fungi pada UMB. Hasil pengamatan secara kualitatif yaitu 1 tidak ada miselia, 2 sedikit miselia, 3 sedang, dan 4 banyak miselia. Berdasarkan hasil penelitian menunjukkan bahwa jumlah miselia pada P1 sampai dengan P4 tidak terdapat terlalu banyak miselia. Menurut pendapat Widiastuti (2013) bahwa pakan yang baik tidak ditumbuhi miselia atau jamur.

\section{Pengaruh perlakuan terhadap tekstur}

Hasil analisis statistik pada Tabel 2. menunjukkan bahwa perlakuan yang dilakukan dalam penyusunan UMB menunjukkan hasil yang tidak berbeda nyata $(\mathrm{P}<0,05)$ terhadap tekstur UMB. Hasil pengamatan secara kualitatif yaitu 1 remah, 2 agak keras, dan 3 keras. Berdasarkan hasil tersebut bahwa hasil P1 menunjukkan hasil yang tidak terlalu keras.

Tekstur pakan dipengaruhi oleh kehalusan bahan baku, jumlah serat, dan jenis bahan pengikat yang digunakan. Penambahan perekat akan membantu bahan pakan untuk saling mengikat satu sama lain, sehingga akan menyebabkan terjadinya perubahan tekstur menjadi lebih padat. Widiastuti (2013) menambahkan bahwa kualitas tekstur dipengaruhi oleh kadar air dan serat kasar pada pakan, pakan yang mengandung serat kasar tinggi akan membuat tekstur menjadi keras.

\section{KESIMPULAN}

Penambahan molases pada UMB sampai dengan $40 \%$ menunjukkan hasil yang baik ditinjau dari warna, aroma, miselia, dan tekstur. 


\section{DAFTAR PUSTAKA}

Anwar, \& Suganda. (2002). Pemanfaatan Limbah Cair Pabrik Gula Tebu Bagi Upaya Meningkatkan Kesuburan Lahan. Proyek Pengkajian Teknologi Pertanian Partisipasif (PAATP). Departemen Pertanian: Badan Penelitian Dan Pengembangan Pertanian.

BPTP Bengkulu. (2015). Urea Molasses Block Pakan Suplemen Ternak Ruminansia. Bengkulu: Balai Pengkajian Teknologi Pertanian.
Utami, B. (2009). Pengolahan Dan Pemanfaatan Limbah Pabrik Gula (Mollases). Jurusan Teknik Kimia. Surakarta: Jurusan Teknik Kimia. Fakultas Teknik. Universitas Muhammadiyah.

Utomo, R. (2012). Evaluasi Pakan Dengan Metode Noninovatif. Yogyakarta: PT Citra Aji Parama.

Widyastuti, Y. (2008). Fermentasi silase dan manfaat probiotik silase bagi ruminansia. Media Peternakan, 31(3), 225-232. 